\title{
Wastewater Treatment of a Cardboard Manufacturing Plant by Infiltration Percolation
}

\author{
Amal Bellarbi, Mohamed Monkade, Abdellah Zradba and Abdelghani Laameyem \\ Department of Physics, Faculty of Science, Chouaib Doukkali University, ElJadida City 24000, Morocco
}

\begin{abstract}
Different coastal sands of the city of El Jadida are used to filter wastewater from a cardboard manufacturing plant combined with fly ash and bottom ash (by-products of a local power plant). The performances of five matrices of these elements are compared in infiltration-percolation in vertical columns. The study of particle size sand is performed beforehand. The chemical and mineralogical composition of fly ash and bottom ash are produced by X-ray fluorescence and X-ray diffraction respectively. The wastewater samples were collected during a complete cycle of production of the cardboard. The heavy metals content before and after filtration was obtained by atomic emission spectrometry with inductively coupled plasma (ICP-AES). The parameters analyzed were: total suspended solids (TSS), organic matter $\mathrm{COD}, \mathrm{BOD}_{5}$, the potential hydrogen $\mathrm{pH}$ and heavy metals (iron, zinc and arsenic). The results are very conclusive and respect the essence of control required by Moroccan regulations (law 1606-06) related to discharges from the papermaking and cardboard industry.
\end{abstract}

Key words: Percolation infiltration, fly ash, bottom ash, wastewater, cardboard.

\section{Introduction}

The waste management is a major challenge for all countries. To prevent its abundance in nature, it is recommended to store these byproducts in landfills [1, 2]. However, this storage raises two problems - the first is economic like the management and development of landfills; the second is environmental: presence the risk of contamination of water and soil in case of infiltration of harmful elements like heavy metals (arsenic, cadmium, lead, iron and zinc).

The local thermal power-Jorf Lasfar Energy Company (JLEC) generates a large amounts of ash (fly and bottom ash) which amounts to more than $800,000 \mathrm{t} /$ year [3, 4]. If fly ash is practically a valorized part in the manufacture of cement, the bottom ash portion, which varies between $5 \%$ and $20 \%$ is stored in a landfill. One of the main objectives is to find a way of valorization for these wastes, particular in the treatment of wastewater and also in road construction [4] and building materials [5]. In the

Corresponding author: Amal Bellarbi, engineer, research fields: wastewater treatment and waste valorization. E-mail: a.bellarbi@gmail.com. context of the study, the focus is on the treatment of wastewater from a cardboard manufacturing plant by percolated infiltration on natural porous materials and industrial waste. Sand filtration is a very old method used for wastewater treatment [6].

This purification method remains the method of choice not only in rural areas but also in many industrialized countries. The authors' contribution in this study is the combination use of natural porous materials (sand) with industrial waste (fly ash and bottom ash from thermal power plants) [7]. The goal is to give them a second life in the wastewater treatment generated by cardboard manufacturing plant in Morocco.

\section{Materials and Methods}

\subsection{Physico-Chemical Characterization of Wastewater}

\subsubsection{Sampling}

Samples of analyzed wastewater were carefully removed in order to obtain the most representative sample possible. The samples were conducted for $24 \mathrm{~h}$ (sampling every $2 \mathrm{~h}$ ). The average volume of each sample was 1 liter. The samples were collected in 
glass bottles, stored in a cooler and transported immediately to the laboratory.

\subsubsection{Physico-Chemical Analysis}

The physico-chemical parameters were chosen following the regulatory requirements with respect to Moroccan discharge limits for paper and cardboard industry (law 1606-06 laying down specific limit values for wastewater discharge of the pulp, paper and cardboard manufacturing plant) [8].

The results were also compared to Canadian standards [9]. The study was limited to the following parameters:

- Temperature, $\mathrm{pH}, \mathrm{COD}, \mathrm{BOD}_{5}$ and MES;

- Heavy metals: Arsenic (As), Zinc (Zn) and Iron (Fe).

All physico-chemical parameters of wastewater were determined by the wastewater analytical standard methods [7]. The content of suspended solids (TSS) was determined by the filtration method. The chemical oxygen demand (COD) was analyzed using a COD meter thermo-type reactor Behr TRS 300 and biological oxygen demand $\left(\mathrm{BOD}_{5}\right)$ was measured using an Oximeter 538 (WTW)/BOD meter: TS606/2. Heavy metals were determined by atomic emission spectrometry with inductively coupled plasma (ICP-AES).

\subsection{Requirements of the Moroccan Regulations}

The Table 1 presents the requirements of the Moroccan regulations on discharges from the paper and cardboard industry in Morocco.

\subsection{Structures and Morphologies of Adsorbents Used}

\subsubsection{Bottom Ash}

The bottom ash used in the percolating infiltration experiments are produced in the Jorf Lasfar thermal power plant "JLEC" which located at a distance of 24 $\mathrm{km}$ from El Jadidacity on the cost road to Safi. They appear as porous dark grains more or less gray. However, samples of bottom ash in this study are black with a highly variable particle size. Fig. 1 gives the visual aspect [5].

The sampled bottom ash had been previously sifted. The authors chose to work with a particle size of the bottom ash that is less than $3 \mathrm{~mm}$, this increases the contact surface of the bottom ash grains with substances from the wastewater and improve the adsorption.

The chemical composition of bottom ash is obtained by fluorescence $\mathrm{X}$ technique.

This is a non-destructive elemental analysis technique which allows multiple dosing of basic materials compounds.

The mineralogical composition bottom ash is obtained by $\mathrm{X}$ ray diffraction technique.

\subsubsection{Fly Ash}

The fly ash is the fine powders from burnt pulverized coal in boilers of thermal power plants at Jorf Lasfar "JLEC".

Table 1 Release limit values of the paper and cardboard manufacturing in Morocco [8].

\begin{tabular}{ll}
\hline Parameters & Moroccan regulation \\
\hline temperature $\left({ }^{\circ} \mathrm{C}\right)$ & $\begin{array}{l}\text { Do not exceed } 10{ }^{\circ} \mathrm{C} \text { the temperature of } \\
\text { the receiving environment }\end{array}$ \\
$\mathrm{PH}$ & $5.5-8.5$ \\
$\mathrm{COD}\left(\mathrm{mg} \mathrm{O}_{2} / \mathrm{L}\right)$ & 900 \\
$\mathrm{BOD}_{5}(\mathrm{mg} \mathrm{O} / \mathrm{L})$ & 200 \\
$\operatorname{MES}(\mathrm{mg} / \mathrm{L})$ & 400 \\
Arsenic $(\mathrm{mg} / \mathrm{L})$ & 0.1 \\
Iron $(\mathrm{mg} / \mathrm{L})$ & 3 \\
Zinc $(\mathrm{mg} / \mathrm{L})$ & 2 \\
\hline
\end{tabular}

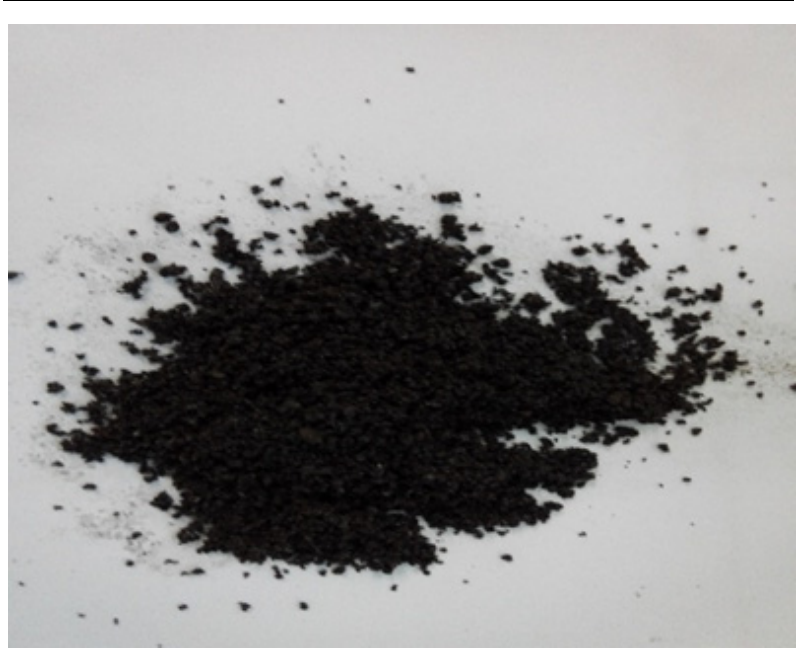

Fig. 1 Visual aspect of bottom ash. 
They are driven by the flow of gaseous waste generated by the combustion reaction and thus, captured by electrostatic filters which separate the gaseous discharges.

The samples of fly ash are gray in color and have a smooth and shiny surface [10]. It is fine and resembles a cement powder (Fig. 2).

The fly ash is removed from the combustion of coal that comes from South Africa. Each sample was obtained by quartering from several samples of $5 \mathrm{~kg}$. The quartering is to divide the sample into four equal parts. Two opposite parts are recovered and homogenized. One of these latter two parts is subject to a new quartering. The operation can be repeated three or four times in order to obtain a representative sample [11].

As part of this study, fly ash has been chemically characterized using the technique of spectroscopy flame atomic absorption (ICP) and a mineralogical characterization established by X-ray diffraction.

\subsubsection{The Sands}

Samples of sand that were used in the experiments percolation filtration were collected from $86 \mathrm{~km}$ of coastline of El Jadida between El Oualidia and El Haouzia which are indicated on Fig. 3.

Table 2 presents details of the sites of our samples of sand. These were in the first step, carefully washed with distilled water then dried at $40{ }^{\circ} \mathrm{C}$ in a stove [12]. They were then sifted to determine the various sizes.

The authors conducted a detailed analysis of particle size of 5 types of sands [11] on a column of 12 sieves (standard method NF P 18-560) [7]. This involved passing a quantity of 100 grams of sand through the 12 sieves, they were ranked in descending order (AFNOR standard) and to which a mechanical vibratory movement was applied for 30 minutes.

\section{Results and Discussion}

\subsection{Physico-Chemical Composition of Wastewater}

As shown in Table 3, the wastewater of cardboard is characterized by a very high $\mathrm{COD}, \mathrm{BOD}_{5}$, TSS and some metals like iron and zinc, whose values exceed the specific limit discharges values applicable to discharges from paper and cardboard industries in public sanitation.

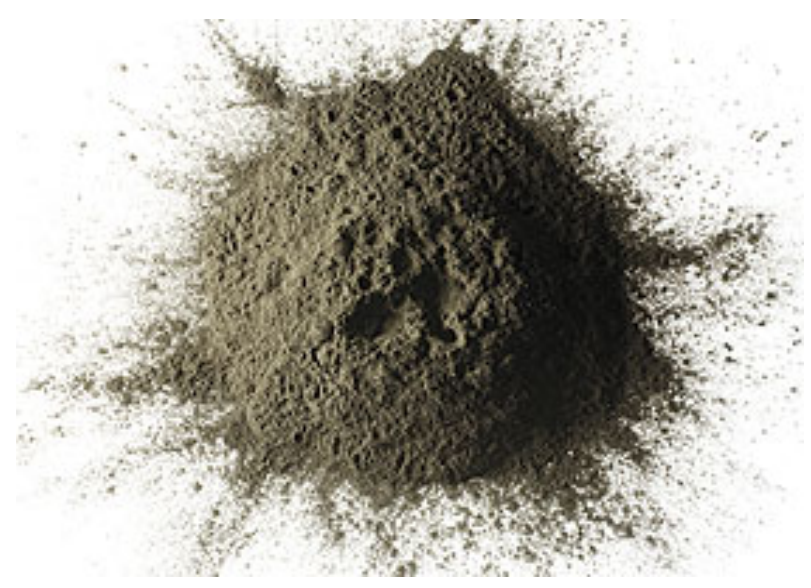

Fig. 2 Visual aspect of fly ash.

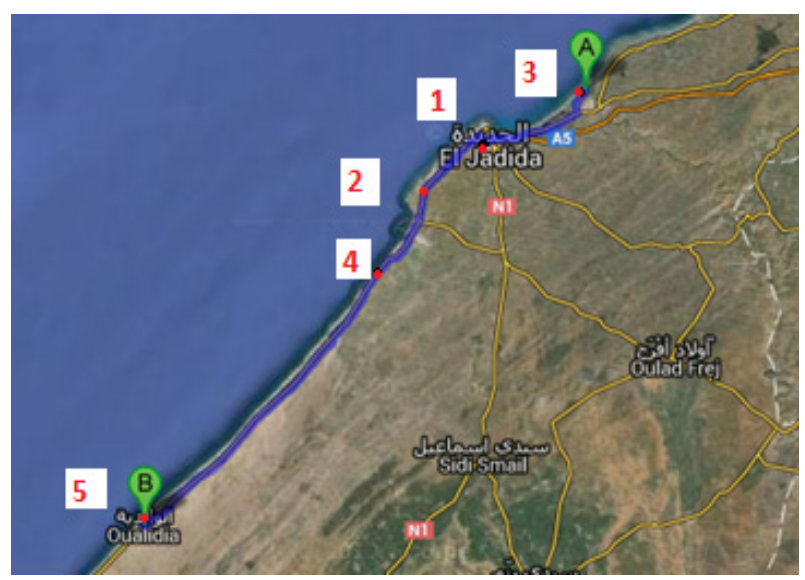

Fig. 3 Sampling sites sand samples.

Table 2 Situation of sand sampling sites.

\begin{tabular}{ll}
\hline Sand & Situation \\
\hline Sand 1 & El Jadida Beach \\
Sand 2 & Sidi Bouzid Beach ( $8 \mathrm{~km}$ from El Jadida on the coastal road to Safi) \\
Sand 3 & El Haouzia Beach $(20 \mathrm{~km}$ from El Jadida on the coastal road to Casablanca) \\
Sand 4 & Sidi Abed Beach $(31 \mathrm{~km}$ from El Jadida on the coastal road to Safi) \\
Sand 5 & El Oualidia Beach (78 km from El Jadida on the coastal road to Safi) \\
\hline
\end{tabular}


Table 3 Physical and chemical analyzes of the studied wastewater.

\begin{tabular}{ll}
\hline Parameters & Value \\
\hline Temperature $\left({ }^{\circ} \mathrm{C}\right)$ & 27 \\
$\mathrm{PH}$ & 6.03 \\
$\mathrm{COD}\left(\mathrm{mg} \mathrm{O}_{2} / \mathrm{L}\right)$ & 17,606 \\
$\mathrm{BOD}_{5}(\mathrm{mg} \mathrm{O} / \mathrm{L})$ & 4,053 \\
$\mathrm{TSS}(\mathrm{mg} / \mathrm{L})$ & 4,232 \\
Arsenic $(\mathrm{mg} / \mathrm{L})$ & 0.014 \\
Iron $(\mathrm{mg} / \mathrm{L})$ & 15.8 \\
Zinc $(\mathrm{mg} / \mathrm{L})$ & 2.51 \\
\hline
\end{tabular}

\subsubsection{Bottom Ash}

The results of analysis of the chemical composition of bottom ash JLEC are supplied in Table 4 .

It was note that over $80 \%$ of the chemical composition of bottom ash consists of elements $\mathrm{SiO}_{2}$, $\mathrm{Al}_{2} \mathrm{O}_{3}$ and $\mathrm{Fe}_{2} \mathrm{O}_{3}$. However, for lime, it hardly exceeds $2 \%$.

The bottom ash mineralogical composition is obtained by ray diffraction technique. This study reveals the existence of two peaks. The first quartz $\left(\mathrm{SiO}_{2}\right)$ and the second corresponds to mullite (Fig. 4). This result is explained by the mineralogy of the coal used, which generally consists of crystalline silica form of quartz and clay minerals phyllitheux group (shale).

\subsubsection{Fly Ash}

The analysis results of the chemical composition of fly ash are reported in Table 5 .

The chemical composition of fly ash shows that the sum of the percentages of components: $\mathrm{SiO}_{2}, \mathrm{Al}_{2} \mathrm{O}_{3}$ and $\mathrm{Fe}_{2} \mathrm{O}_{3}$ is $94.4 \%$, classifies it among the silico-aluminous ashes [13].

The mineralogical composition of the fly ash is shown in Fig. 5.
The result of this experiment reveals the existence of two peaks, quartz and mullite. During combustion, these minerals change structure and give birth to a low crystallized portion in the form of mullite and quartz and an amorphous part [4]. This result agrees well with the mineralogical composition of bottom ash.

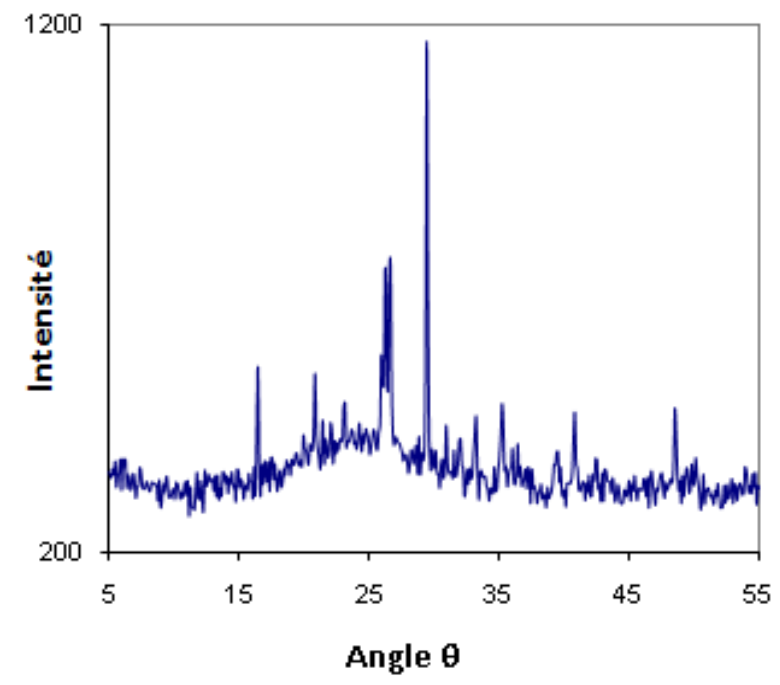

Fig. 4 Mineralogical spectrum of bottom ash.

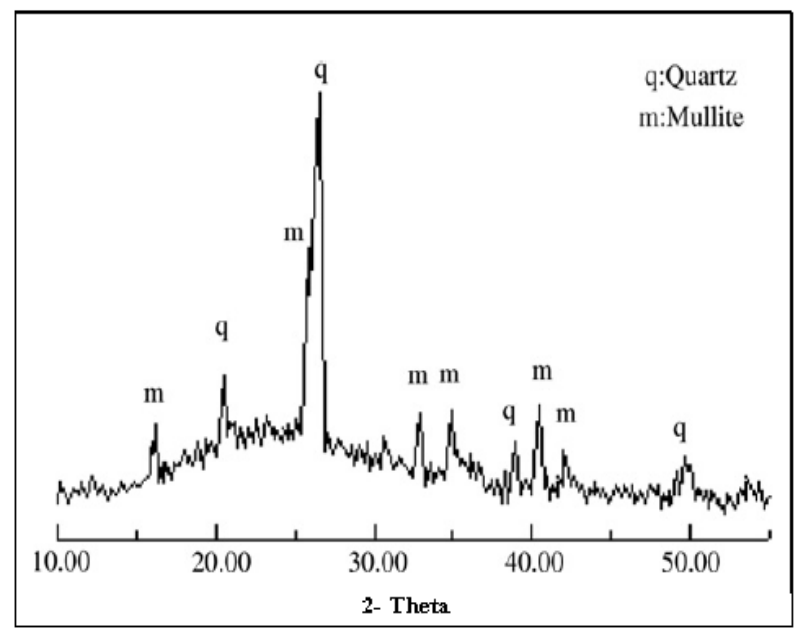

Fig. 5 Mineralogical spectrum of fly ash.

Table 4 Chemical composition (in mass \%) of bottom ash.

\begin{tabular}{lllllllllll}
\hline $\mathrm{CaO}$ & $\mathrm{SiO}_{2}$ & $\mathrm{Fe}_{2} \mathrm{O}_{3}$ & $\mathrm{Al}_{2} \mathrm{O}_{3}$ & $\mathrm{~K}_{2} \mathrm{O}$ & $\mathrm{Na}_{2} \mathrm{O}$ & $\mathrm{ZnO}$ & $\mathrm{PbO}$ & $\mathrm{SO}_{3}$ & $\mathrm{MgO}$ & Free $\mathrm{CaO}$ \\
\hline 1.92 & 52.07 & 8.86 & 23.34 & 1.9 & 0.4 & 0.01 & 0.01 & 1.87 & 1.09 & 0.29 \\
\hline
\end{tabular}

Table 5 Chemical composition (in mass \%) of fly ash.

\begin{tabular}{llllllll}
\hline $\mathrm{SiO}_{2}(\%)$ & $\mathrm{Al}_{2} \mathrm{O}_{3}(\%)$ & $\mathrm{Fe}_{2} \mathrm{O}_{3}(\%)$ & $\sum\left(\mathrm{SiO}_{2}+\mathrm{Al}_{2} \mathrm{O}_{3}+\mathrm{Fe}_{2} \mathrm{O}_{3}\right)(\%)$ & $\mathrm{CaO}(\%)$ & $\mathrm{MgO}(\%)$ & $\mathrm{SO}_{3}(\%)$ & $\mathrm{K}_{2} \mathrm{O}(\%)$ \\
\hline 57 & 34 & 3.4 & 94.4 & 10 & 0.02 & 0.5 & 1.2 \\
\hline
\end{tabular}




\subsubsection{The Sands}

Graphical representations of particle size analyzes of five sand used are shown in Figs. 6-10.

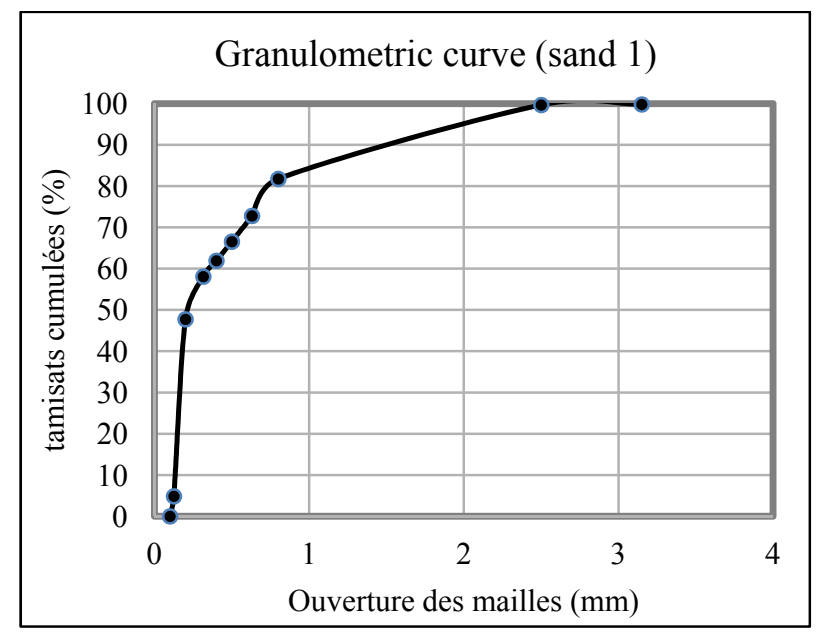

Fig. 6 Particle size curve of EI Jadida sand.

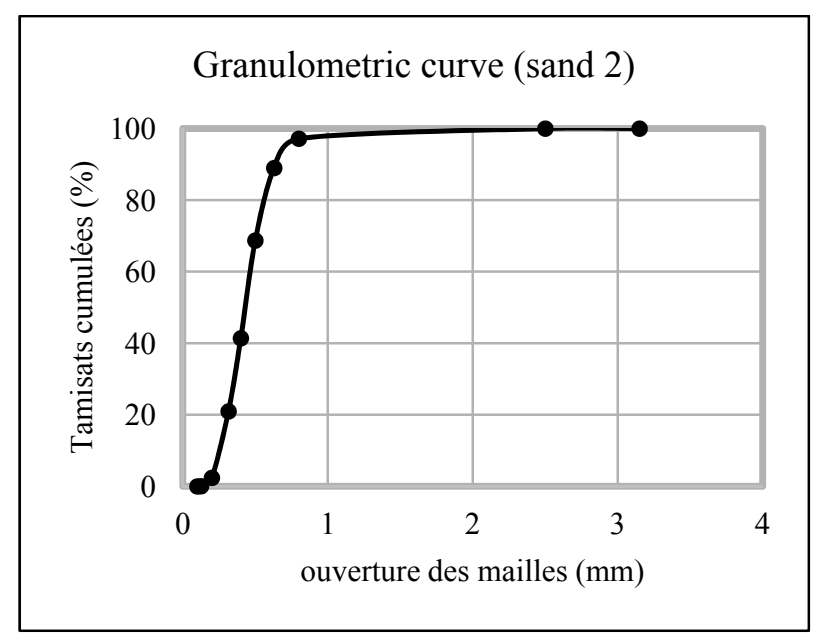

Fig. 7 Particle size curve of Sidi Bouzid sand.

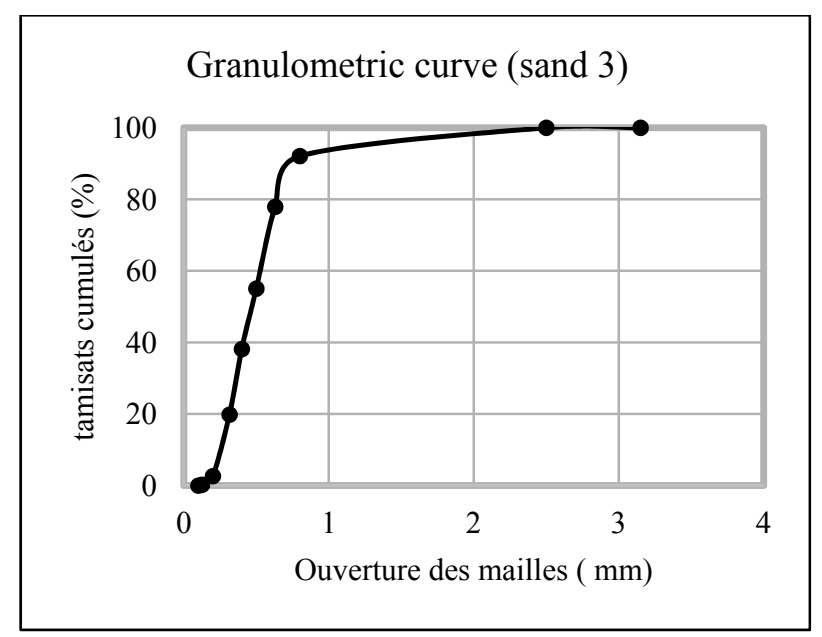

Fig. 8 Particle size curve of El Haouzia sand.

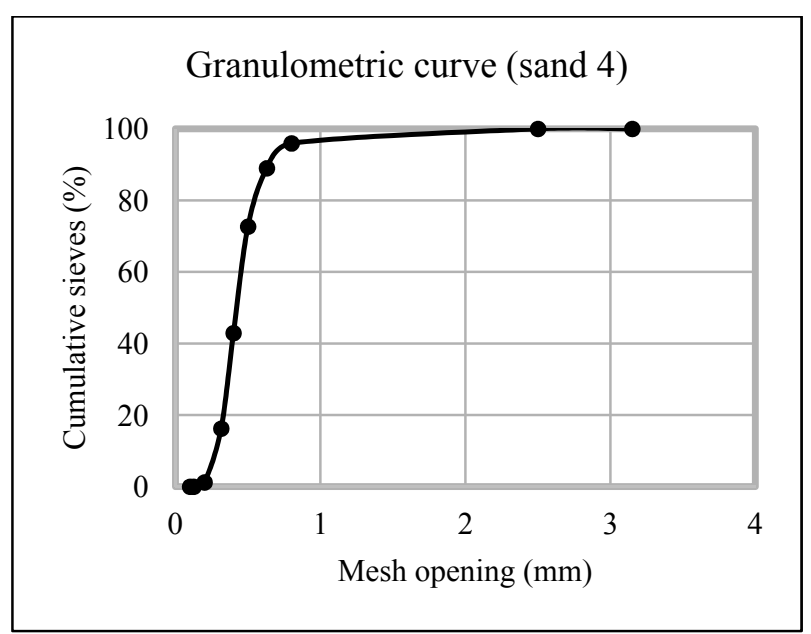

Fig. 9 Particle size curve of Sidi Abed sand.

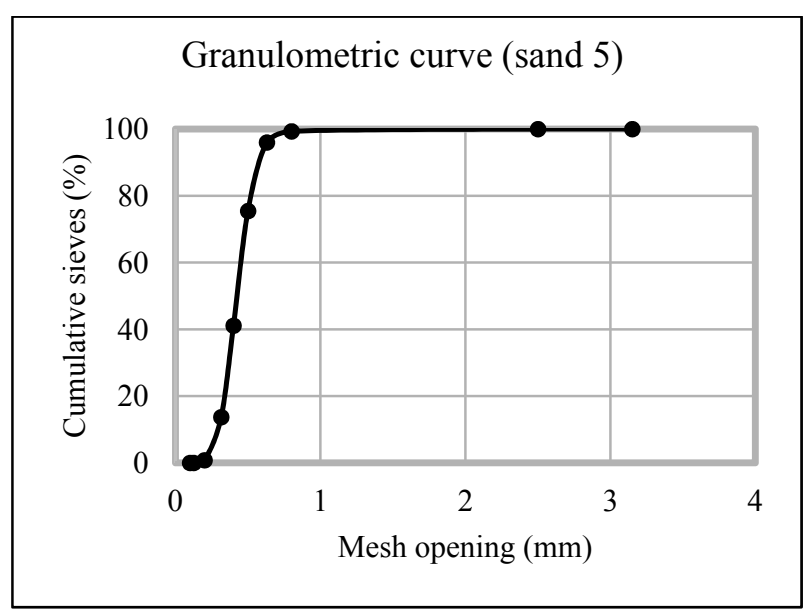

Fig. 10 Particle size curve of El Oualidia sand.

From the above particle size distribution curves for 5 sands, it reaches $90 \%$ of cumulative undersize passing through mesh screen between 400 and 500 microns. The authors can conclude that the predominant size of the studied sands is between 400 microns and 500 microns, which attributed it to the class of fine sand [14]. The small particle size of the latter facilitates the fixation of the organic material to the surface of adsorbent material which is generally more important when the particle size of the material is low.

In the filtration tests of wastewater from the cardboard, it was used a sample of each type of sand and used fractions $\leq 600 \mu \mathrm{m}$.

\subsection{Results of Wastewater Infiltration Percolation Tests}

Fig. 11 shows the results of filtration of wastewater. 


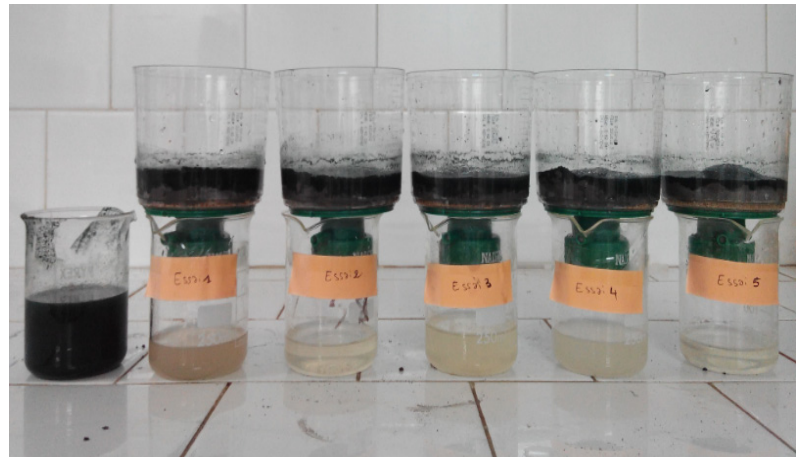

Fig. 11 Visual aspect of different matrices filtrates (fly ash

+ bottom ash + (sand), $(i=1, \ldots 5))$.

The five filters used consist of three layers: fly ash (FA), Bottom (BA) and sand. On the other filter which changed only the sand samples following sites as indicated on Table 2.

As shown in the results below, a remarkable discoloration is obtained using fly ash-bottom ash sand-matrix.

Previous studies have shown the effectiveness of the sand/fly ash filter in the context of synthetic discoloration [15]. The addition of bottom ash in this case gives interesting results, especially for matrix 2 and 5, which obtained a significant improvement in visual and olfactory level.

\subsubsection{Abatement of COD}

The wastewater treated by the filter beds 1-2-3-4-5 test shows a reduction of organic pollution in terms of COD with an average reduction rate of $75 \%$ and with a minimum content of $769 \mathrm{mg} / \mathrm{L}$ COD value that complies with current regulations $(900 \mathrm{mg} / \mathrm{L})$. While, the initial COD value of the sample before treatment is $17,606 \mathrm{mg} / \mathrm{L}$ (Fig. 12).

\subsubsection{Abatement of Suspended Matter}

Analysis of the suspended matter can identify the amount of undissolved material (colloid), whether organic or inorganic, present in the sample. Wastewater studied is highly charged with suspended matter $4,232 \mathrm{mg} / \mathrm{L}$.

This treatment can achieve an average reduction rate of $96.7 \%$ with a minimum TSS content of 180 $\mathrm{mg} / \mathrm{L}$ value that complies with current regulations (400 mg/L) (Fig. 13).

\subsubsection{Abatement of $\mathrm{BOD}_{5}$}

The wastewater treated by the filter beds 1-2-3-4-5 test shows a reduction of organic pollution: $\mathrm{BOD}_{5}$ has an average reduction rate of $94.85 \%$ and a minimum content of $180 \mathrm{mg} \mathrm{BOD} / \mathrm{L}$ value that complies with current regulations $(200 \mathrm{mg} / \mathrm{L})$. The initial $\mathrm{BOD}_{5}$ of the sample before treatment was $4,053 \mathrm{mg} / \mathrm{L}$ (Fig. 14).

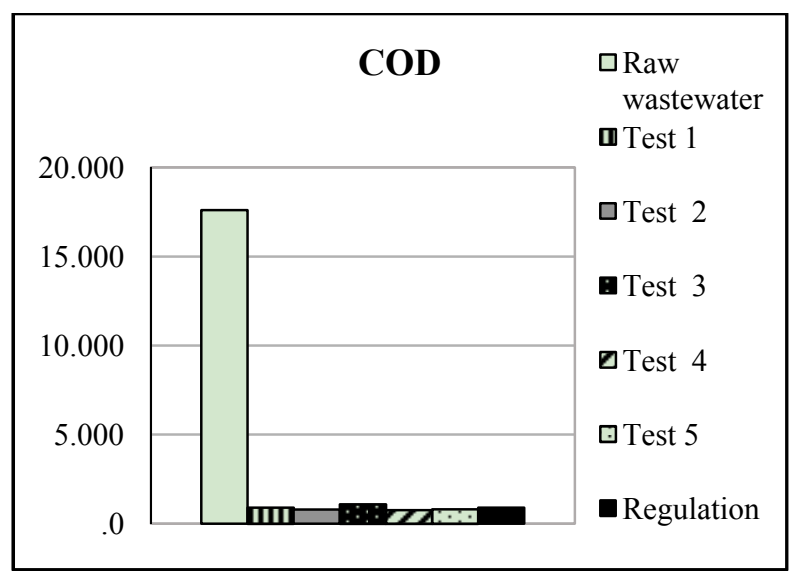

Fig. 12 Abatement of COD.

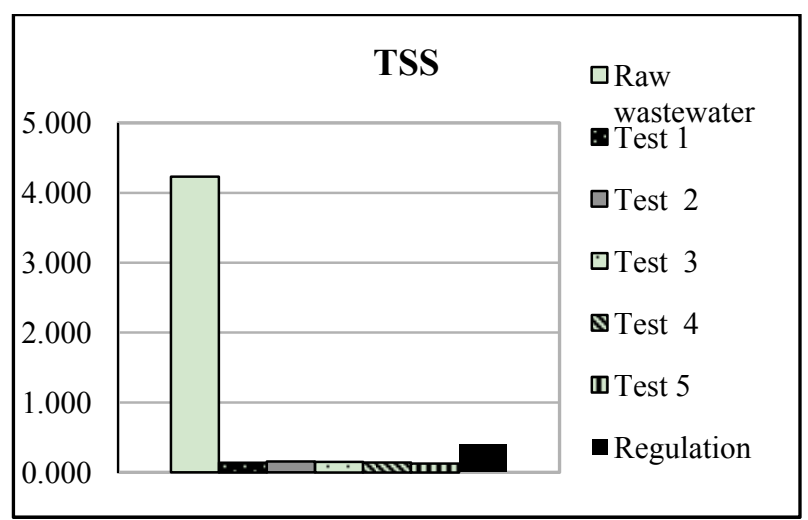

Fig. 13 Abatement of suspended matter.

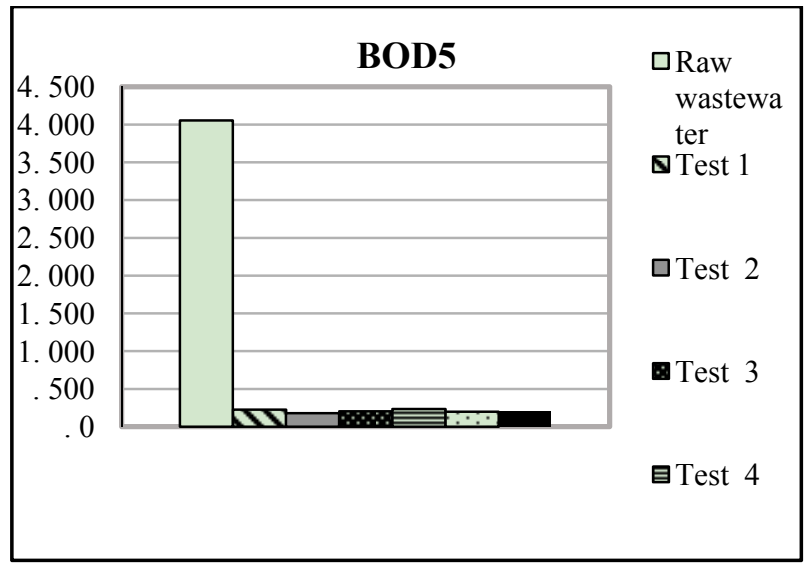

Fig. 14 Abatement of BOD $_{5}$. 


\subsubsection{PH Evolution}

Wastewater treated by the test filter beds 1-2-3-4-5 shows the $\mathrm{pH}$ neutralization (Fig. 15). The studied wastewater has a $\mathrm{pH}$ of 6 , while all the tests helped neutralize discharges ( $\mathrm{pH}$ between 7.3 and 7.5). These $\mathrm{pH}$ values meet the regulations in force $(\mathrm{pH}$ between 5.5 and 8.5$)$.

3.3.5 Abatement of Heavy Metals: Zinc, Iron and Arsenic

The cardboard wastewater treatment by the sand, fly ash and bottom ash bed filtration has enabled the authors to achieve a zinc abatement rate of $79 \%$ and a reduction rate of $81 \%$ iron with minimum values of $0.478 \mathrm{mg} / \mathrm{L}$ and $2.84 \mathrm{mg} / \mathrm{L}$ respectively that meet current regulations.

These high values of iron and zinc in the wastewater can be a source of the printing inks used (Figs. 16-18).

For arsenic analysis of rejection has allowed the authors to identify the very low concentration of arsenic and that respects the current regulations.

\subsection{Results Analysis}

The origins of polluting effect of wastewater from the cardboard factory are:

- The water of cleaning printing machines and gluing;

- Leakage of inks and glues used.

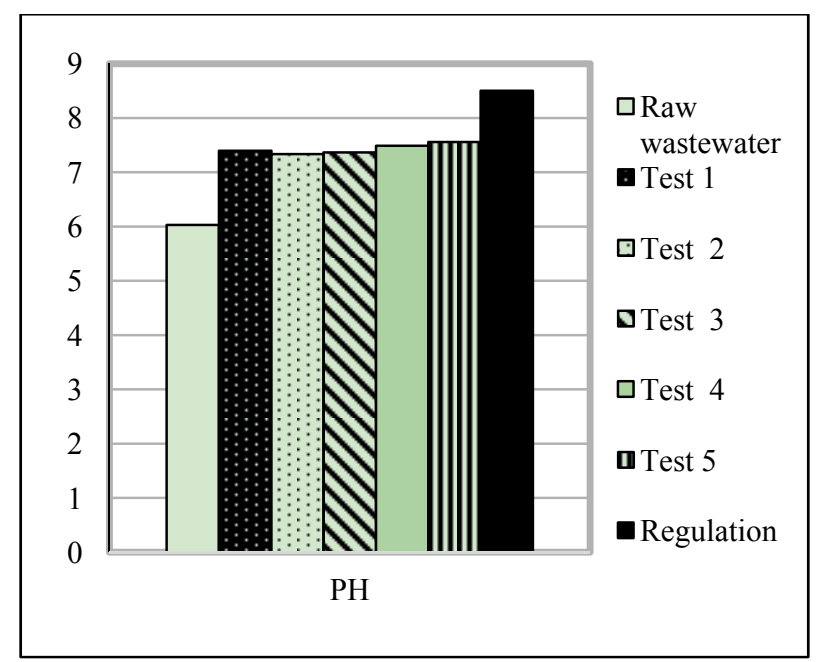

Fig. 15 PH neutralization.

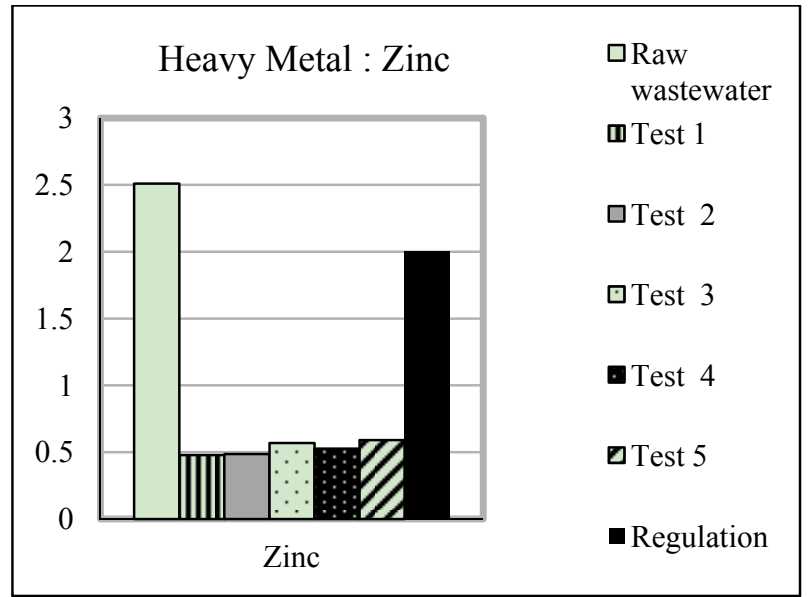

Fig. 16 Abatement of zinc.

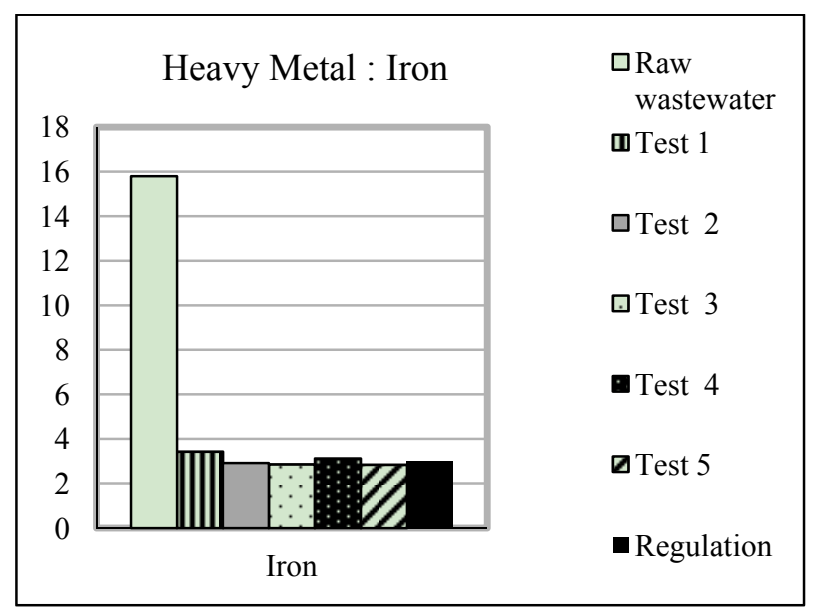

Fig. 17 Abatement of iron.

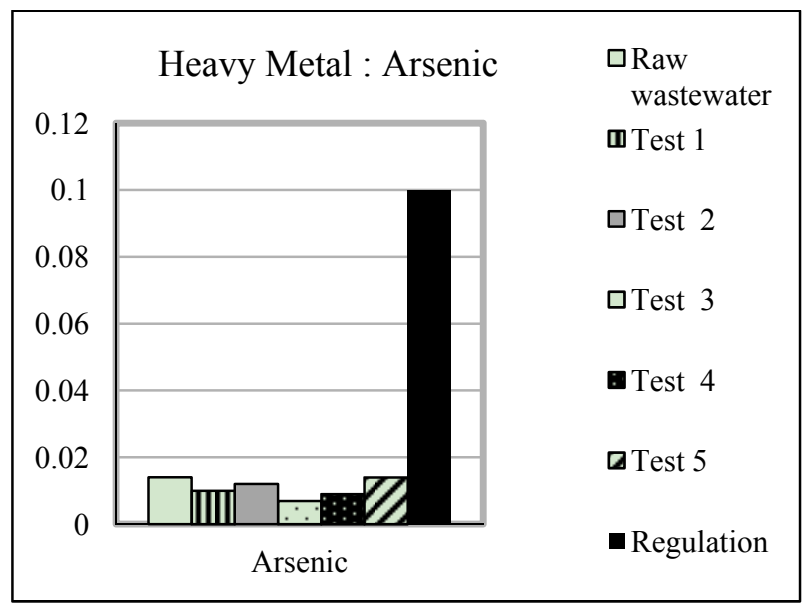

Fig. 18 Abatement of arsenic.

Environmental monitoring of wastewater from the cardboard during a complete production cycle $(24 \mathrm{~h}$ : start lines, normal cycle of production, stopping, end of the day and cleaning) shows that the concentrations 
of $\mathrm{COD}$ and $\mathrm{BOD}_{5}$ increase in the end of day - a time of cleaning. The ratio $\mathrm{COD} / \mathrm{BOD}_{5}$ being about 4.34 (> 3), which makes this hardly biodegradable water.

The optimal treatment is the separation of water to pollutant and determining a way of treatment or valorization of this pollutant.

As shown in the results below (Fig. 11), a remarkable discoloration is obtained using the sand-fly ash-bottom ash matrix.

The best discoloration is observed for test 5 and test 2 , test 4 , test 3 and the less degree discoloration is observed with test 1 .

Sands used in test 1 will be taken as the starting optimization in sand-fly ash and bottom ash filter.

The high abatement rates of organic matter (COD, $\mathrm{BOD}_{5}$ and TSS) is explained by the composition of bottom ash and fly ash used that the two types of waste are rich in $\mathrm{SiO}_{2}$ elements, $\mathrm{Al}_{2} \mathrm{O}_{3}$ and $\mathrm{Fe}_{2} \mathrm{O}_{3}$ is more than $80 \%$ of their compositions [16]. The iron and aluminum oxides are the essential raw materials for the manufacture of water and wastewater treatment coagulants [17].

As regards heavy metals, the rate of elimination is remarkable due to the adsorption properties of the fly ash and bottom ash — containing a high content of silica. An important adsorbent has a high electrical polarity and nutrients in particular ferrous ions $\left(\mathrm{Fe}^{3+}\right)$ which contribute to the neutralization of negative charges contained in the wastewater.

\section{Conclusion}

This study aimed to characterize the cardboard manufacturing wastewater and demonstrate that natural adsorbents like sand or some industrial wastes such as fly ash and bottom ash which could be used as filtration support for treatment of wastewater from the paper and cardboard industry.

The results obtained showed that:

(1) Studied wastewater does not meet the standards of Moroccan and international releases of the paper and cardboard industry for physicochemical parameters studied;

(2) Filtering through the matrix (marine sand/fly ash/bottom ash) enables effective reduction of organic and inorganic pollutant charge. The results of the tests have reached an abatement rate of $75 \% \mathrm{COD}, \mathrm{BOD}_{5}$ 95\% of the MES 97\%. They also allowed a significant reduction in heavy metals such as zinc and iron (respectively abatement rate $79 \%$ and $81 \%$ ). The results obtained are compared successfully with International and Moroccan standards;

(3) Comparison of five matrices shows that the sands of the various sites in the region of El Jadida suitable for this type of wastewater treatment process. Quantification of olfactory and visual pollution of water obtained after infiltration is a perspective of this work. The optimization of the matrix (marine sand/fly ash/bottom ash) is being implemented with the aim of passing on the scale of a pilot treatment plant.

\section{References}

[1] Ben, Abou, M., and El-Haji, M. 2014. "Treatments by Electrocoagulation-Filtration of Uncontrolled Leachate Discharge from the City of Taza and Re-use in the Germination of Sorghum and Alfalfa International." Journal of Innovation and Applied Studies 9 (1): 355-366.

[2] El, Ouafi, and Socoin, M. 2010. Environment Impact Study Relative to the Jorf-Lasfar Thermal Power Extension Project. Impact Study report.

[3] El-Moudni, S., El-Alami, M., and Monkade, K. Lahlou. 2009. Valorisation of a Mixture of Thermal Power Buttom Ash and Steel Slag in Road Engineering. France: Francophone Revue of Industrial Ecology.

[4] El-Moudni, S., and El, Alami. 2000. "Contribution to the Valorization of Coal Ash and Steel Slag in Civil Engineering." Ph.D. thesis, University of Chouaib Doukkali.

[5] Maazouzi, A., Ketteb, A., and Badri, A. 2007. "Study on Sand Filtration Processes of Bechar Region in Pretreatment of Drinking Water." Desalination 206 (2007): 358-368.

[6] Najem, M. 2013. "Valorisation Des Matériaux Dans Le Traitement Des Eaux Usées Par Infiltration Percolation: Sur Du Sable, Sol, Argile Cendres." Ph.D. thesis, University of Chouaib Doukkali.

[7] F.A.O. 2006. Stopped Laying Down the Specific Limits of Rejection of Paper Pulp, Paper and Cardboard Industries. Morocco: Moroccan Regulation. 
[8] The Council of the Montreal Metropolitan Community. 2008. Regulation No. 2008-47 on Water Sanitation. Canada: Canadian Regulation.

[9] Adamiec, P., Benezet, J. C., and Benhassaine, A. 2005. "Relation between Silico-Aluminous Fly Ash and Coal Mining." Poudres \& Grains 15 (3): 35-46.

[10] Liénard, A., Ghellaf, H., and Catherine, Bouttin. "Choice of Sand Percolation Infiltration Beds." Journal of Enigineering 66: 59.

[11] Laamyem, A., Najem, M., Monkade, M., Zradba, A., and Radouani, N. 2010. "Adjustment of Fly Ash in the Purification of Industrial Wastewater from El Jadida City." Revue Eau Industrieet Les Nuisances 332: 101-104.

[12] Moufti, A. 2003. "Physicochemical Study of Mine Water from Youssoufia Morocco and Defluoridation by Adsorption on Cellulose and Coal Fly Ash.” Ph.D. thesis, Chouaib Doukkali University.

[13] Najem, M., and Laamyem, A. I. T. 2009. "Lançar Catchment of Heavy Metals from Industrial Wastewater by Percolation Filtration through a Soil-Sand Layer." Revue Eau Industrieet Les Nuisances 327: 92-96.

[14] Smahi, D., Fekri, A., and El-Hammoumi, W. 2013. "Assessment of the Impact of the Landfill on Groundwater Quality: A Case Study of the Mediouna Site, Casablanca, Morocco." Journal of Water Resource and Protection 5: 440-445.

[15] Aarfane, A., Salhi, A., El, Krati, M., Tahiri, S., Monkade, M., and Lhadi, E. et al. 2014. "Kinetic and Thermodynamic Study of the Adsorption of Red195 and Methylene Blue Dyes on Fly Ash and Bottom Ash in Aqueous Medium." J. Mater Environ. Sci. 5 (6): 1927-1939.

[16] Sun Wei-Ling, Qu Yan-Zhi, Yu Qing, and Ni Jin-Ren. 2008. "Adsorption of Organic Pollutants from Coking and Papermaking Wastewaters by Bottom Ash." Journal of Hazardous Materials 154: 595-601.

[17] Fan, M., Brown, R., Wheelock, A. T., Cooper, M., and Nomura, Y. Zhuang. 2005. "Production of a Complex Coagulant from Fly Ash.” Chem. Eng. J. 106: 269-277. 